\title{
Moral regeneration: Seedbeds for civic virtue ${ }^{1}$
}

\author{
Piet G J Meiring \\ Department of Science of Religion and Missiology \\ University of Pretoria
}

\begin{abstract}
Taking his cue from a recent report by the US National Council on Civil Society, the author discusses a number of "seedbeds of civic virtue" that may play a role in the much needed moral regeneration of South African society. The "seedbeds" are (1) family, (2) the local community, (3) faith communities, (4) voluntary civil organizations, (5) arts and art institutions, (6) education, (7) business, labour and economic institutions, (8) the media, (9) government, (10) the nation. The "rainbow nation", the author contends, has in recent times lost some of its colour, but if the different partners in the quest for moral regeneration take hands, the colours of the rainbow may return.
\end{abstract}

\section{INTRODUCTION: THE RAINBOW HAS FADED}

I bought three newspapers yesterday (5 March 2003): The Sowetan, Beeld and The Pretoria News. A catalogue of woe awaits one, page after page. This surely, is not the South Africa we all envisaged when Madiba embraced the world and smiled his famous smile on that glorious day in Pretoria, in May 1994, when the Rainbow People danced in the streets, the day the dream of a truly new South Africa seemed to have been realized. Allow me to quote some of the headlines:

- $\quad$ Soccer boss back in court, after a false declaration of personal income amounting to $\mathrm{R} 7,2$ million.

- $\quad$ Two members of the North Rand Police Dog Unit guilty of assaulting immigrants. Racism evidently played a role.

- $\quad$ Farmer (79) attacked on his farm at Skeerpoort.

\footnotetext{
${ }^{1}$ Address delivered at the S A Council of Churches' Conference: A Charter for Churches on Moral Regeneration, University of South Africa, Pretoria, 6 March 2003.
} 


\section{Moral regeneration: Seedbeds for civic virtue}

- $\quad$ Yengeni (former party whip) must go, says ANC.

- $\quad$ Addy Moolman and co-accused Winny Madikizela Mandela: "We supplied false data".

- $\quad$ Mafia style murder case: Centurion woman (24) murdered.

- $\quad$ S A Revenue Service gets tough on tax dodgers.

- Rape accused posed as cop.

- $\quad$ Two Muslim women found dead on main road.

- How to guard against security firms.

What happened to our society? "Most people are moral", the ANC states in a position paper on Ethical Transformation (ANC 1998:3):

They are not criminals advocating unethical behaviour. They wish to bring up their children to be honest, with the desire to build a prosperous and peaceful South Africa for all who live in it.

The cultures brought together in our nation also had high ethical standards. Traditional African cultures were modelled on morals. Afrikanerdom was prompted by strict adherence to spiritual values. Those who traced their origins in other countries also recognise high concepts of personal and social responsibility.

Many of our people are religious. Whether we follow traditional religion, Hinduism, Judaism, Christianity or Islam, the call to personal and ethical behaviour is similar. Humanists who are unbelievers accept he same universal moral goals. People prefer to be good.

But things have changed: the Rainbow has lost its colour. South Africa has become a violent, even dangerous place to live in. It was to be expected, many experts say. We live in a time of rapid social change. We still struggle with the heritage of apartheid. But how do we remedy that? How do we regain our moral standards?

My charge is to try and show how we may be able to link up with others and to find partners, in our quest for moral regeneration - and with their help, try and understand the issues we need to address

\section{SEEDBEDS OF CIVIC VIRTUE}

Four years ago, the US Council or Civil Society published a report, A Call To Civil Society. Why Democracy Needs Moral Truths, in which the same concerns we have are voiced. In a strange way South Africans, reading the report, may take 
heart. We are not alone in our battle against moral decay. Sociologists, church leaders, politicians, journalists, all South Africans who are calling for moral regeneration, have allies in the wider world - in this instance, in the United States of America.

One of the council members, the analyst Daniel Yankelovich, reported that "public distress about the state of our social morality has reached nearly universal proportions: 87 percent of the public fear that something is fundamentally wrong with America's moral condition, up from 76 percent a year ago" (US Report 1998:4)

The report also quotes the findings of a recent Gallup Pole: 78 percent of the public rates "the state of moral values in this country" as either very weak or somewhat weak. About 76 percent of Americans believe that moral values have deteriorated in the past 25 years (US Report 1998:4).

Similar polls in other countries of the world would no doubt demonstrate the same concerns. Moral decay seems to be a worldwide phenomenon as well as concern. What do interest me in the USA report are the remedies suggested, as well as the discussion of the different role players in the quest for moral regeneration. Much of what the report says may be of use to South Africans in their quest for moral regeneration.

There exist, the report says, groups in society who are able to rekindle a sense of morality. The report refers to them as seedbeds of civic virtue. The report mentions at least twelve of these seedbeds - and reading through the report made me think: not all of them, but most of these seedbeds of civic virtue are also to be found in South Africa. These are the people, the institutions of society, we have to partner with in our quest. I have rearranged the US list, dropped one or two, but consider the following ${ }^{2}$ seedbeds of civic virtue:

\subsection{The family}

The family, sociologists maintain, is the cradle of citizenship, since it is in the family that a child first learns, or fails to learn, the essential qualities we so clearly need in our society: honesty, trust, loyalty, co-operation, self-restraint, civility,

\footnotetext{
${ }^{2}$ In the US Report twelve seedbeds of civic virtue are mentioned: (1) the family, (2) the local community, (3) faith communities and religious organizations, (4) voluntary civic organizations, (5) arts and art institutions, (6) local government, (7) primary and secondary education, (8) higher education, (9) business, labour, and economic institutions, (10) media institutions, (11) a shared civic faith and a common civic purpose, (12) a public moral philosophy.
} 
compassion, personal responsibility and respect for others. "As an institution", the US reports states, "the family's distinguishing trait is its powerful combination of love, discipline and permanence. Accordingly, families can teach standards of personal conduct that cannot be enforced by law, but which are indispensable traits for a democratic civil society" (US Report 1998:7).

Our first link, therefore, should be with the families across the land. In South Africa however the question is: where are the families? Arguably the worst legacy of apartheid is the breakdown of family life, the creation of a system that resulted in millions of fathers, mothers and children living separated from one another, with little chance of a normal family life, of learning traditional family values.

It goes without saying that the breakdown of family life is not unique to Souh Africa, and apartheid is not the only cause in this regard. It happens everywhere in the world, in highly industrialized as well as rural communities. But it is more than clear that the breakdown of family life was exacerbated by the social manipulation of the apartheid system. The question is: how long will it take to rebuild a society with healthy families in South Africa where traditional positive family values may be rediscovered and enjoyed by young and old together?

When the Moral Regeneration Movement (MRM) was recently launched in South Africa (Pretoria 2002), the plight of family life as well as the rebuilding of family relationships topped the agenda. From all the provinces concerns about the breakdown of family life and the weakening of family structures were tabled. Participants at the Moral Summit regarded the family as the major tool for nurturing sound ethics, of behavioural and social values in the community. Family life has to be strengthened in order to play its role effectively (MRM 2003:7f):

The absence of fathers, or the loss of dignity of fathers through substance abuse, is a major problem. Some children have not known a mother either. Many hardly see parents who are at work. The lack of parental guidance, role modeling, and control, leaves many children without security. Consequently, many struggle to find identity and meaning in their lives.

Many children are subjected to mental, physical or sexual abuse by parents or family relatives, which often leaves them damaged for life, unable to see the positive and life-giving value of family. A growing number of them are orphaned through AIDS. 
The elderly are becoming increasingly neglected in our society. Their wisdom and experience are no longer valued and they are considered more as an economic liability than as a source of moral guidance and inspiration.

Married couples struggle to deepen or maintain their relationships, often leading to divorce and its attendant social and economic problems.

No true renewal of family life is possible without full expression of the dignity and equality of women.

Much is being done to restore and rebuild family relationships. Government structures, local organizations and NGOs are working hand in hand with churches in this regard. But that much more is to be done to empower South African families - the most important agent for nurturing values, attitudes, and behaviour (MRM 2003:8) - is evident.

\subsection{The local community or neighbourhood}

All people need safe, stable environments in which they can play in the parks, go to the library, walk out the front door to be with other people, to help one another, to offer guidance to one another's children, to learn from each other, to enjoy one another, where children may learn to take responsibility. "Historically", the US report states, "the US has always been an amalgam of diverse and vital neighborhoods, in this sense more a community of communities than a unitarian national culture" (US Report 1998:8). Democracies need such communities, local environments in which men and women maintain a common life, rooted in collective memory and shared values.

The challenge to South Africans is to restore our neighbourhoods, to rebuild communal life. Through the machinations of apartheid as well as the processes of industrialization and urbanization our society was uprooted. Millions were displaced by political and economic forces. In the cities black townships were developed with little regard for the societal needs of the inhabitants. Hundreds of thousands of men were required to live in hostels. Great numbers of men and women and children found themselves in shantytowns and squatter camps. For many years local communities were seedbeds of division, of prejudice and of violence. Apartheid made people distrust one another, distanced from one another. Now we have to reverse the tide and restore our local 
communities, where people may rediscover and enjoy one another: black and white, men and women, Christians, Muslims, and Hindus.

"No one is born hating another person because of the colour of his skin, or his background, or his religion", Nelson Mandela wrote. "People must learn to hate, and if they can learn to hate they can be taught to love, for love comes more naturally to the human heart than its opposite" (ANC 1998:4). We need communities where parents can confidently tell their children: "Go outside and play. Learn how to live!"

\subsection{Faith communities and institutions}

South Africa is a thoroughly religious country with the vast majority of its citizens belonging to Christian churches, but also with small but strong Muslim, Hindu and Jewish communities (cf Hendriks \& Erasmus 2002:13ff, for recent statistics). The call to personal and communal ethical behaviour is part and parcel of each of these religions. It therefore goes without saying that the faith communities and religious institutions are to play a major part in rebuilding the moral fibre of the country.

Sadly, this is not always the case. Some years ago another study on the role of the Church in American society was undertaken in the USA. The title of the report (1969) was carefully chosen: The church - mirror or window? The implication was obvious: in society the church can choose the role it wants to play. It can act as a mirror image of society by being so caught up in the community, becoming so bureaucraticised, so involved in public affairs, so fixed in its inherited ideas and traditions and prejudices, that it has no message for society. But there is a second possibility. The church may act as a window through which a tortured society, inundated with the problems of the day, can gain new insight. The church can, with the Gospel of Christ in its hand, open new perspectives - and positively assist in influencing and changing society (Whitley 1969; cf De Villiers 2000:220ff).

What is true of the USA is true of South Africa. Throughout the years the churches in the country, too, made their choice. There were times when the churches were but mirror images of our traumatized community, reflecting all the pain, powerlessness, prejudice and racism that were found in other strata of the community. At the South African Truth and Reconciliation Commission's special hearing for faith communities (East London, 17-19 November 1997), leaders from 
one denomination after the other - as was the case with representatives from the Muslim, Hindu and Jewish communities - had to confess their complicity in apartheid, their inability to effectively withstand the pressures of racism and prejudice and injustice (Meiring 1999:265ff). Fortunately there were times, too, when churches - the leaders as well as the laity - stood up to speak and to act, to provide a window of hope to the millions who suffered in South Africa. We had our prophets, who fearlessly spoke about justice and mercy, about walking humbly with God (Mi 6:1-8). We had our priests, who in the footsteps of the Master they served, knelt down to serve and to heal - often as wounded healers. Similarly the faithful in the Hindu, Muslim and Jewish communities often rose to the challenge, to provide a new vision, a new example, to their fellow South Africans.

The Church is still regarded as the most trusted institution in society, according to a recent national survey by the Human Sciences Research Council (2000) - asking respondents to rate their trust in a number of institutions, among them the Church. In spite of the failures and disappointments of the past - it was found that 78 percent of respondents in Kwazulu-Natal and 69 percent of respondents in the Western and Northern Cape trusted the Church above all. All population groups were in agreement: the churches were the institutions to be trusted most. Blacks and Coloureds had the highest score, followed by Whites. Indians (69 percent) recorded the lowest percentage (Siaki 2002:39).

This leaves the church with an enormous challenge. Will the churches, the different denominations in South Africa, use the trust invested in them wisely? Will the Christian community provide the moral leadership and ethical guidance sorely needed in the country? In many Western European countries the churches have lost the trust of the community, and have become largely irrelevant to the day to day lives of the people, with little moral influence. Are the South African churches - as well as the other faith communities - going to use their opportunities in a better way?

\subsection{Voluntary civil organisations}

More than a century and a half ago (in the 1830's), Alexis de Torcqeville sang the praises of the American "voluntary associations", describing them as a hallmark of American exceptionalism and as a defining trait of American civil society. These organizations, the US report emphasises, should be valued and maintained at all cost (US Report 1998:8ff). These organisations made America 
what it is, shaped its society. "Consider just a few current examples", the Report says, "book clubs, Little League, the Future Farmers of America, the Kiwanis Club, the Girl Scouts, the Chamber of Commerce, the Advertising Council, and the National Association for the Advancement of Colored People" (US Report 1998:8f). Much of the dynamism and cultural variety of the US society, the tradition of respect for one another, the spirit of enterprise, the shaping of ideals and practices depend on these organizations.

South Africa, too, has a long history of voluntary organizations. The role of the Non Governmental Organisations (NGOs) and the Community Based Organisations (CBOs) is vast. The impact of the NGOs and CBOs as well as their contribution to the change that eventually did come to South Africa are equally important. In post-apartheid South Africa, however, things have changed. Many NGOs and CBOs find themselves in the doldrums. With the demise of apartheid their agenda has changed and their backing has diminished. Their raison d'etre has disappeared! Other organizations - cultural, educational, religious, et cetera - are also struggling to redefine their aims and goals, to find the necessary support for their activities.

The challenge to us all is: Can new life be blown into the community of voluntary organisations? Can we once again harness the enthusiasm and expertise of the voluntary NGOs and CBOs, providing them with a new agenda: that of moral regeneration, of fighting for a more humane community where ethical values, once again, will flourish? To quote but one example: During the TRC years Khulumani (literally: "let us talk") Groups went out on a limb to support the many victims of apartheid, to see to it that justice was done to them. We need a new generation of Khulumani organisations who start talking about corruption and crime, raising their voices against violence against women and children, who research the reasons and the context of moral decay - and who are willing to act and to campaign for a better, cleaner, more humane social environment.

\subsection{The arts and art institutions}

An often neglected or underestimated seedbed of civic virtue is that of the arts and of art institutions. "Music, poetry, dance, theatre, painting, literature, sculpture, architecture, are the crucial legends and components of civil society", the American report states. "Fundamentally they are statements of meaning and aspiration. They also inevitably ask and answer moral questions: what is good or 
bad, what is true or false" (US Report 1998:9). The arts and art institutions, at their best, affirm the core values of civil society. They provide models of beauty and standards of clarity. They, too, serve as mirrors in which we see ourselves at our worst and at our best. The arts elevate the public discourse, they activate the imagination. Artists and art institutions are indispensable comrades in our quest for a better society.

It goes without saying that in the South African quest for moral regeneration the role of the arts and of art institutions should be recognized and encouraged. Strangely, in the material of the Moral Regenaration Movement, reference to the contribution by the arts is nowhere mentioned - as is the case in the statement on Ethical Renewal, developed by the ANC. This must be an oversight, uncharacteristic of the South African community where singing and dancing, drama and comedy, usually accompany national and local events and endeavours, where painting and sculpture as well as other expressions of art, are held in high regard. The point that has to me made over and over again is: we need the artists of our day. They are the interpreters, the social commentators, the prophets, the creators and the celebrants of the community we sorely need.

\subsection{Education}

It is universally accepted that a basic responsibility of primary, secondary as well as tertiary educational institutions, is cultural transmission, passing on to a new generation a "civilization story in which they can all share, in part by teaching them the skills to participate in and help shape their story" (US Report 1998:10; my italics). In addition to teaching basis intellectual skills schools are called upon to embody as well as require basic standards of good conduct: personal responsibility, respect for authority, respect for one's peers, training students in the art of civil life, explaining to them what good citizenship is all about, challenging them to accept and embrace their society's civic and moral ideals.

The US Report contains an interesting observation, which South Africans may choose to take seriously:

If you could look only in one place to take the deepest measure of our civilization, where would you look? Some would choose to look at our religious ideas and institutions. Others would choose our system of higher education. Especially in our era, when the social authority of 
religious belief has weakened, and when more young people than ever go on to some form of higher education, the modern university may be our truest cultural barometer, our most accurate indicator of who we are becoming.

(US Report 1998:10)

In South Africa the issue of education is hotly debated. Reference is often made to the educational system inherited from an unjust past, to structures that were inherently immoral, designed to enhance the education of one race group and diminish the opportunities of others (MRM 2003:9). It is taking, and will take, enormous efforts and imaginative thinking to redress the imbalance. It will take as much effort to create a curriculum which can live up to the expectations voiced in the paragraphs above, a curriculum that not only informs and teaches skills, but which embodies and requires basic standards of good conduct. It is obvious that the discussion between the government and the religious community in the country on the place awarded to religion in the schools, of religious instruction in the curriculum, as well as the role to be played by teachers as well as local religious leaders in this regard, is far from finished. If moral regeneration is our top priority, national as well as local governmental structures should reach out to the faith communities, as well as to other civil institutions, to lend a hand. We need one another dearly in the battle for moral renewal.

Sport is an important part of education and of moral formation. In its research the MRM recorded a glaring lack of proper sport facilities at many schools. Many MRM focus groups saw this as a primary factor contributing to an absence of socialisation which is mandatory for training young people in the skills of team work, caring for one another, discipline and commitment. Sport should be revived as a social activity for fun and not for competition. This includes the recovery of indigenous games - enabling participants to relate sport to culture. Sport, the MRM emphasizes, often provides a sense of belonging for participants who lack it at home (MRM 2003:9).

\subsection{Business, labour and economic institutions}

Business and economic institutions play an increasingly important role in civil society. For millions in the world the workplace is a primary source of personal identity, a central venue for social relationships. Many Americans, the US Report 
states, experience the workplace as even more influential than neighbourhood, church or even family. Moreover, Americans have long believed that the experience of work itself - of giving honest value in return for fair reward - can be a builder of good character. Similarly, while private companies in free market economies operate in part "according to the calculus of rational self-interest", they are also pervaded by dense webs of moral ties and conventions. Private firms therefore are major custodians - and can themselves become creators or destroyers - of social competence, moral concern and social trust (US Report 1998:11).

The contribution not only in creating a more just economic dispensation in South Africa, but to help build a new moral order in the country can not be overemphasised. Labour as well as business, trade unions as well as management, share a huge responsibility in shaping our country, in building up the moral fibre of our people, in deciding the ethical standards we live and work by. The churches should continuously engage these institutions, not only in finding solutions for the economic discrepancies in society, to address the perennial question of affluence and poverty, but to create a code of moral conduct for management and workers alike (cf Painter-Morland 2000:17; Childs, 1995:5ff). Such a code of conduct could have a rippling effect on our society and may benefit not only the people directly involved, but millions of South Africans in all walks of life, in ever extending circles.

\subsection{The media and media institutions}

In the US report the media is seen as the seedbed that is "most rapidly expanding in size and influence". It is also blamed by most as the institution mostly responsible for the collapse of the social and moral order. American parents and educators by and large blame the media industry for the changes in family life, as well as in the socialization of children. The cultural values, promulgated by radio, film, television and other electronic media are overtly and increasingly hostile to the values they want their children to acquire. The media is blamed for many ills in the US society: the rise of cynicism, the decline of face-toface civil engagement, and the spread of incivility (US Report 1998:11).

Many South Africans would echo that. The influence of the media - printed as well as electronic - on young and old, is vast. What people believe and think, the issues they discuss, the political parties they vote for, the sport they support, 
how they behave towards one another, the taste they acquire, their moral behaviour, is largely dictated by radio, television and the movies, as well as by the daily press. Reference is often made of the extent to which the media in this country has been co-opted by North American cultural imperialism. One has only to look at the popularity of the so-called "soaps" on radio and television, a recent report states. Added to this is the ever-increasing screening of sex, violence and obscene language. Parental Guidance warnings are often inadequate because many children live in homes with absentee parents (MRM 2003:11).

This, too, has not only to do with individual life, but with society at large. One of the most important institutional hearings conducted by the South African Truth and Reconciliation Commission was the Media Sector Hearing, 15-17 (September 1997), significantly held in one of the large television studios of the South African Broadcasting Corporation in Johannesburg. Attention was focused during the hearing on the role played by the media not only in disseminating news and propaganda, but also by blatantly or inadvertently upholding the unjust system of apartheid in South Africa (TRC Report, IV, 1998:165). But the point is that the media can and should also be used as a strong ally in the battle for morality, for nurturing positive behaviour and an interest in the community at large.

The media is vital in conveying the message of moral regeneration. "The media is not 'out there"', the Moral Regeneration Movement reminds us. "They (the media) live in our neigbourhoods, they are our family and friends and they have a conscience" (MRM 2003:11). The media, the MRM maintains, has the potential to influence ideas and values in a most profound way. For this reason media ownership and direction needs to be transparent and accountable, and journalists should be well and truly committed to honesty and integrity in their

profession. Far greater local content in our television programming is needed, as well as the publication of "good news" stories and programmes that promote transformation and the alleviation of poverty, profiling persons of integrity as role models for the youth - as well as for their parents (cf ANC 1998:11).

\subsection{Government}

It struck me that, in contrast to what would have been the case in South Africa, the role allocated to the state in bringing about moral regeneration, was considered by the US Report to be virtually at the bottom of the list. We tend to 
define government among the primary role players, shouldering the real responsibility for social behaviour and for moral regeneration. It may well be that we too easily shift the responsibility to the State, that we expect of the government to do what we as members of civil society ought to have done. But that does not take away the fact that the government - on local, provincial as well as national level - does have an inescapable responsibility towards nation building, towards creating a healthy moral environment. Government does that by its legislative programme, by its civil service, by providing for and maintaining a functional administration, by nurturing a respect for law and for the juridical process among its citizens - and especially by political leaders setting the example to the people of the land.

We have to continuously remind the government, the people and parties we elected to parliament of their awesome responsibility, not only towards the nation, but towards itself. The state, as is the case with other institutions, owe the nation leaders who are perceived to be persons of integrity, men and women who are willing to set good examples and who set the standards of morality. We may expect from political leaders the formulation of a code of conduct to which they themselves adhere, the implementation of a "moral audit" among themselves that may serve as a challenge to all South Africans.

\subsection{The final seedbed of civil virtue is the nation itself}

We need constantly to remind ourselves as South Africans, as one nation, of who we are, by what moral code and ideals and by what ethical standards we want to live. According to the US Report (1998:12), creating a new moral order has everything to do with nation building. This will be done in South Africa, the ANC position paper contends, "by accepting responsibility for ourselves, not by blaming others" (ANC 1998:10). It requires commitment by every sector of society to build a nation with a sound ethical base, and of every individual South African an equally strong commitment to participate in the process. Good people make good nations! During the apartheid regime it was often said: "The State will do it!" Many spent years opposing oppression by saying: "The state must not do it!" Now again, discussing the need for transformation for rebuilding our country, people are saying: "No state must do it!" This is wrong. In a democratic society we live by the dictum: the people shall govern. The ultimate responsibility for the country therefore lies with us, the people (ANC 1998:10). 
But, then, the people need to have confidence in who they are, in the direction they are going, and in the role they are playing to secure that future. We have been fortunate. Politically and economically, events of the past decade seem to have been going our way. But, strangely, South Africans do not feel good about themselves. Louis Fourie and J P Landman, in their enquiry on how South Africa is faring in the international community, rates the country's overall performance positively, with the exception of one or two areas of concern. One of these areas is the South African nation's self-esteem. We lack the necessary self-confidence, they maintain, because in spite of many efforts, also by the South African Truth and Reconciliation Commission, we have not adequately dealt with our communal past (1998:7):

We as South Africans come from a bitter history. A history that did not deteriorate to a full-scale civil war, but one that nevertheless left more than one generation with serious physical, mental, psychological and moral scars. Our civil war took place in people's hearts and left many of us with critical injuries inside.

Many people in South Africa totally underestimate the consequences of this background and even bluntly deny history's effects on their personal psyches. They hide these internal scars behind a coverup and artificial behaviour. They need to realize that there is "a virus in the software" that can only be eliminated through serious introspection, intensive care and a real willingness to address the problem.

One of the results of not having dealt adequately with the past, is that disrespect, institutionally as well as individually, has become endemic in South Africa, and needs to be addressed as a matter of high priority. If it does not happen the function of the nation as a seedbed of civic virtue will be seriously hampered. Fourie and Landman (2002:88) make a strong plea for the return of respect in South African society, as well as a rediscovery of the worth of every individual:

The results [of the chronic disrespect] can be seen in basic wellness indicators: the average life expectancy of a South African is 47, we have the highest murder rate per capita in the world, we are the only country with statistically meaningful infant rapes and we see commuters trash and burn stations when trains are late.

South Africans are truly suffering from the disease identified by Kofi Annan: "Remember the individual, and then the larger aims will not seem distant or impossible .... What begins with the failure to uphold 
the dignity of one life, all too often ends with a calamity for entire nations".

To succeed as a seedbed of virtue - to harness the nation's energy on it's way to the future - the nation needs a clear direction of where it is going. And the more diverse the nation is, the clearer the direction needs to be defined, communicated and directed. In highly developed First World countries, people tend to get along well without an articulated national vision. In fact, to talk to Americans and Britons about a "national vision" would be met with puzzlement, if not outright suspicion. But in less developed communities, such as South Africa, a national vision is a sine qua non. Strong and visionary leadership is required to bond the people together in pursuit of this common goal. Fourie and Landman (2002:111) emphasize: "In order for people to perceive themselves as part of a community, they need to believe that their goals are cooperative and that they share a common purpose". This, sadly, is not happening. Ask the average South African to identify our country's one non-negotiable, politically untouchable national goal, you get any number of vague answers. In fact, nobody really knows, because there is no such vision.

In order to serve as a seedbed of civic virtue the nation needs to mobilise all the energy and spirit it possesses to forge South Africans into one nation, and to create a simple, wise, national goal, for all to follow. We need to focus the minds of all South Africans, to guide them on their way to a new and better future.

\section{COLOUR THE RAINBOW!}

I started off by quoting the headlines from three local newspapers, to indicate how the colours of the "Rainbow Nation" the past decade, have faded. I could have used other sources, for instance quoting learned articles published on the subject or from public addresses by South African leaders and academics. The Stellenbosch professor Willie Esterhuyse, for instance, at the Klein Karroo National Arts Festival (Oudtshoorn, March 2000) bemoaned a situation in which the levels of crime indicate "the serious erosion of the social order and acceptable value systems" in South Africa (NG Kerk 2002:226). None other than the president, Thabo Mbeki, in turn, in his keynote address to the Cape Town Anti-Corruption Summit (April 1999) solemnly declared: "What I am trying to suggest is that our society evolved in a manner which gave birth to a situation in 


\section{Moral regeneration: Seedbeds for civic virtue}

which a disastrous collapse of social values occurred, to be replaced by the notion that what is good, is what serves my individual material interests and pleasures" (NG Kerk 2002:226).

The time has come to redress the situation! Fortunately, we are not alone in our quest for moral regeneration. We have numerous partners from many spheres of society. There are a number of "seedbeds of civic virtue" that may be used to restore our national morality, to repaint South Africa in all the colours of the rainbow. Allow the families, the local communities, the faith communities, the voluntary organizations, the educationalists, the business community, the media, government and the nation to take up the brushes - and see the colours return.

\section{Works consulted}

African National Congress (ANC) 1998. Ethical transformation: ANC statement on the moral renewal of the nation. Johannesburg: ANC.

Childs, J M 1995. Ethics in business: Faith at work. Minneapolis, MN: Fortress Press.

De Villiers, E 2000. "Human rights and moral responsibility: Their relationship in the present South African society". NGTT 49 (3 \& 4), 212-224.

Fourie, L, \& Landman, J P 2002. "South Africa, how are you", published by the authors. (Paarl: Paarl Print.)

Hendriks, J \& Erasmus, J 2002. A general statistical picture of religion in South Africa, in Kritzinger, J J (ed), No quick fixes. Pretoria: IMER.

Moral Regeneration Movement 2003. From liberation to transformation. Johannesburg: MRM.

Meiring, P 1999. Chronicle of the Truth Commission. Vanderbijlpark: Carpe Diem.

National Council on Civil Society (USA) 1998. A call to civil society: Why democracy needs moral truths (A report to the nation from the Council on Civil Society). New York: Institute for American Values.

Ned Geref Kerk (DRC) 2002. Agenda van die Algemene Sinode. Pretoria: N G Kerk.

Painter-Morland, M 2000. Weaving the moral fabric of the South African workplace:

Personal and institutional factors. Address at the conference on Weaving the moral fabric of the South African workplace, University of Pretoria, 2000.

Siaki, P 2002. Christianity in the new South Africa, in Kritzinger, J J (ed), No quick fixes. Pretoria: IMER

South African Truth and Reconciliation Commission 1998. Report, Vol IV, Cape Town: TRC

Whitley, O R 1969. The Church: Mirror or window? St Louis: Bethany. 